\title{
Island narratives in the making of Japan: The Kojiki in geocultural context
}

\author{
Henry Johnson \\ University of Otago \\ henry.johnson@otago.ac.nz
}

\begin{abstract}
Shintō, the national religion of Japan, is grounded in the mythological narratives that are found in the $8^{\text {th }}$-Century chronicle, Kojiki 古事記 (712). Within this early source book of Japanese history, myth, and national origins, there are many accounts of islands (terrestrial and imaginary), which provide a foundation for comprehending the geographical cosmology (i.e., sacred space) of Japan's territorial boundaries and the nearby region in the $8^{\text {th }}$ Century, as well as the ritualistic significance of some of the country's islands to this day. Within a complex geocultural genealogy of gods that links geography to mythology and the Japanese imperial line, land and life were created along with a number of small and large islands. Drawing on theoretical work and case studies that explore the geopolitics of border islands, this article offers a critical study of this ancient work of Japanese history with specific reference to islands and their significance in mapping Japan. Arguing that a characteristic of islandness in Japan has an inherent connection with Shintō religious myth, the article shows how mythological islanding permeates geographic, social, and cultural terrains. The discussion maps the island narratives found in the Kojiki within a framework that identifies and discusses toponymy, geography, and meaning in this island nation's mythology.
\end{abstract}

Keywords: ancient Japan, border islands, geopolitics, Kojiki, mapping, mythology

https://doi.org/10.24043/isj.164 • Received July 2020, Early access June 2021

(C) Island Studies Journal, 2021

\section{Introduction}

This study interprets the significance of islands in Japanese mythological history. The article discusses ancient Japanese literature and focuses on one important $8^{\text {th }}$-Century literary source, the Kojiki 古事記 (712; literally, 'writings about ancient matters'), which describes Japan's origins within an archipelagic discourse, with islands given geographical, religious, and cultural significance. There are other works that describe Japan's origins, some of which are mentioned below, but focus is given to the Kojiki as the first major text that describes Japan's origins through a narrative of islands, both terrestrial and imaginary. Of particular importance in the study of this work is that the archipelagic origins of Japan are not only narrated through myth, but some of those islands are identifiable today and help illustrate the significance of islands within the epistemological fabric of the Japanese geocultural seascape. Moreover, the 
main islands referred to in the Kojiki are interpreted as border islands that help demarcate an emerging geopolitical territory across land and sea, which occupied a sometimes-contested sphere in the northeast Asian region.

There are several versions of the Kojiki, with the oldest complete manuscript to survive dating from the early Muromachi period (1337-1573) (Heldt, 2014, p. xxi). Known as the Shinpukuji-bon (Shinpuku Temple manuscript), this version was actually based on two branches of the work (Heldt, 2014, p. xxi). In the Edo period (1600-1868), the Kojiki was studied within the kokugaku (nativism) movement (Heldt, 2014, p. xxi):

In this scholarly setting [of the national religion, Shintō, and its divine origins], the Kojiki gained the status of a sacred text privileged above all others by virtue of its unrivaled antiquity as the earliest datable written work to survive intact, and because it all but ignores the Buddhist religion that had been an integral element of Japanese culture from the sixth century onward. (Heldt, 2014, p. xxii)

The Kojiki is a history of Japan that dates from the deities that created the country, and divides into three books that include narration, dialogue, song and commentary (Heldt, 2014, p. xiv). In the present discussion, emphasis is placed on distinct examples of island creation in the text in terms of toponymy, and English translations have been utilized for these purposes. Recognizing that the Kojiki is the subject of in-depth literary discussion from historical Japanese perspectives, I have extrapolated pertinent parts of the text as a way of placing them within island studies rather than elucidating its study in its own right. My objective is to comprehend the place of islands in the opening few sections of the text in relation to historical and present-day Japan. For these purposes, and acknowledging the many scholarly editions of the Kojiki, the analyses of the Japanese and English versions in this discussion are based on those in the authoritative Japanese Historical Text Initiative (JHTI) at the University of California at Berkeley. In this database, the Japanese version of the book is sourced from Ôno (1803), and the English translation from the noted translator of Japanese, Donald Philippi (1969). JHTI includes a scan of the Japanese text along with a transcription into modern-day Japanese script. The parts of the text under study have few differences from other versions, the main focus being on the creation of Japan's islands as outlined in the opening pages of the work.

The national religion of Japan, Shinto ('the way of the gods'), is grounded in the mythological narratives that are found in the Kojiki. Within this early source book of imperial history, myth, and national origins (Kōnoshi, 2000), there are many accounts of islands that provide a foundation for comprehending the conceptual geographical cosmology (i.e., sacred space) of the Japanese archipelago's borders of the time, as well as the political and cultural significance of some of the country's islands to this day. The Kojiki was part of a broader imperial project "to construct authoritative national histories [...] to replace all previous versions" (Brownlee, 1987, p. 117). The Kojiki created imperial history (Brownlee, 1991) and was particularly influential in the rise of state Shintō in the Meiji era (1868-1912), which gave rise to Japanese expansionism and ultranationalism in the decades that followed (Antoni, 2011). Within a detailed geocultural genealogy of gods that links mythology to geography, land and life were created in a sea of small and large islands. Some of these islands are known locations that interconnect myth and place, and some are yet to be determined. Such islands 
are culturally produced places that point to an ideal world and often have religious significance that is celebrated through pilgrimage, tourism, and ritual to this day.

Mythical islands have been the subject of diverse scholarly work in the interdisciplinary field of island studies. Topics include fictional islands in historical literature (MacKinnon, 2020), sacred islands in ancient China (Luo \& Grydehøj, 2017), and deity beliefs across islands in the Kuroshio Current (i.e., Okinawa, Jeju, Zhoushan) (Heo \& Lee, 2018). Locating this paper in the field of decolonial island studies (Luo \& Grydehøj, 2017), the discussion draws on theoretical elements pertaining to comprehending islands on their own terms (McCall, 1994), and in connection with the idea of border islands or related concepts (e.g., Baldacchino, 2008; 2017; Batten, 2004; Iwashita, 2016; Kanazawa, 2018). Emphasis is given to concepts of Japanese islands and their embeddedness within a national historico-religious discourse. (Japanese characters are included in the text for all Japanese islands referred to.) Rather than looking at border islands as flashpoints of conflict, I focus on such islands as spatial markers of territory within a discourse of mythological origin that is found in the fabric of Shintō (Nelson, 2000; Palmer, 1994). That is, in Japan, the notion of shima denotes 'island', but "its meaning also extends to 'territory' or 'community", (Suwa, 2007, p. 7). Arguing that a religious characteristic of islandness in Japan has an inherent connection with Shintō myth, I show how this notion permeates geographic, social, and cultural terrains. As such, the discussion maps the opening island narrative of this $8^{\text {th }}$-Century work within a framework that identifies and discusses toponymy, geography, and meaning in this island nation's Shintō mythology. The reason for taking this approach is because, "as elsewhere in East Asia, the early cartographic record in Japan often takes the form of literary allusions rather than actual map artifacts" (Unno, 1994, p. 353).

Japan has a number of ancient chronicles that portray the mythological origins of the archipelagic nation (Miner, Odagiri, \& Morrell, 1985). The Kojiki and Nihon Shoki (720, also known as Nihongi) are particularly significant as comprehensive texts that have had much influence over the past 1300 years. These sources were compiled near the beginning of the Nara period (710-794), when Japan's capital was located in present-day Nara prefecture and ruled by the Yamato Court. This time in Japanese history saw many developments, especially as a result of adopting numerous cultural ideas from the Chinese Tang-dynasty (618-907), including literature, Buddhism, and music. While the Kojiki is well-known today, it was followed by other broader histories of Japan, as summarized in the imperial court's rikkokushi ('six national histories'; see Sakamoto, 1991): Nihon Shoki (720); Shoku Nihongi (797); Nihon Kōki (840); Shoku Nihon Kōki (869); Nihon Montoku Tennō Jitsuroku (879); and Nihon Sandai Jitsuroku (901).

These texts include references to the mythological origins of Japan, and provide knowledge on the lineage of Japanese gods that link directly with the Japanese Emperor. For the purpose of this discussion, I focus on the Kojiki as one of the oldest and most comprehensive sources on Japanese mythology. This text, like the 'six national histories', was "written in order to legitimise the new state order by providing an account of how the world came into being and by tracing the origins of the emperor to the age of the gods" (Shirane, 2007, p. 1). Such histories as the Kojiki and Nihon Shoki "were commissioned by the Yamato court in the early $8^{\text {th }}$ century at a critical period in nation-state building" and the enforcement of "authority, power, and divinity of the sovereign and his or her surrogates" (Shirane, 2007, p. 3). This nation-building links to the geographical boundaries established in the $8^{\text {th }}$ Century 
with the Yamato Court, which were defined through place naming (Duthie, 2015; Plutschow, 1995), and in these works islands are foregrounded as beacons of significance in terms of their physical location in helping to plot Japan's archipelagic and maritime parameters in a broader region with similar territorial claims and origin myths pertaining to islands.

Japan's mythological "islomania" (Durrell, 1953) concerns "thinking with islands" (Gillis, 2007, p. 276) in terms of a dual combination of purpose. One considers islands as the fabric of the birth of the nation, and the other uses islands as a geographical marker of territory within the cultural imagination as explained through "mythical geography" (Gillis, 2007, pp. 280-281). While the idea of a "myth of continents" (Lewis \& Wigen, 1997) might not relate to Japan due to its archipelagic geography, one of its closest neighbours, China, which occupies part of a large continental expanse, has related island myths that express that culture's origins. In a world where islands "have a tenacious hold on the human imagination" (Tuan, 1974, p. 118), and are "closely associated with the myths of both origins and extinctions" (Gillis, 2007, p. 280), Japan's and China's mythical island histories may not be unique, but the close proximity of the cultures, along with related ideas in Korea, reveals geocultural markers that may have similar features but also express cross-border tension through spatial constructs that sought to avoid ambiguous boundaries across land and sea. Indeed, and "above all, it [the island] symbolizes a state of prelapsarian innocence and bliss, quarantined by the sea from the ills of the continent" (Tuan, 1974, p. 118).

Luo and Grydehøj's (2017) examination of conceptions of islands in ancient China reveals that Chinese culture placed much value on islands and archipelagos, and that travel to and searching for islands had an "objective [that] was not territorial acquisition but instead elixir, which rulers of various Imperial Chinese dynasties sought to obtain" (p. 30). An early source of Chinese islanding was Shan Hai Jing (The Classic of Mountains and Seas) from the Warring States period (475 BCE-221 BCE). This work was "a foundational text for Chinese island thinking. It records the Chinese cultural and geographical situation prior to the Qin Dynasty [221 BC to 206 BC], as well as collects Chinese myths and legends" (Luo \& Grydehøj, 2017, p. 32). A later work, the Hainei Shizhou Ji (Records of Ten Islands within the Sea) from the Weijin (220-420 CE) and Southern and Northern Dynasties (420-589 CE) "describes the eponymous ten islands, which are scattered throughout the four seas" (Luo \& Grydehøj, 2017, p. 32). These were important sources that showed similar attention given to islands from one of Japan's closest neighbours.

While there are no extant examples of the official geographic Japanese maps of 646, 738, and 796 (Unno, 1994, p. 366), based on the (possibly exaggerated) views of Japan, the $7^{\text {th }}$-Century Chinese book, Sui shu (History of the Sui Dynasty [581-618]) comments "that it took five months to cross the territory of Wa (Japan) from west to east and three months from north to south" (Unno, 1994, p. 366). Whether or not the travel involved more than one island is unknown, but a later work, the Japanese Engi-shiki (Procedures of the Engi Era) of 927, offered more cartographic detail in its depiction of the country:

The text refers to the boundaries of the territory as being Michinoku in the east, Tōchika in the west, Tosa in the south, and Sado [佐渡] in the north; respectively they are northeastern Honshū, the Gotō Islands [五島] off western Kyūshū [九州], 
a province in southern Shikoku, and an island in the Sea of Japan where the northward curve of Honshū begins to be pronounced. (Unno, 1994, p. 366)

There are some similarities and differences between this work and the Kojiki, but essentially the literary mapping lays claim to territory across land and sea, thereby identifying place and space, or locality and jurisdiction, whether factual or imagined. Other literary works, such as the Soga monogatari (The Tale of the Soga Brothers) also contained references to Japan's borders, and in this book a reference to the Chikura Sea (around Tsushima and Iki, which was a route to China via the Korean peninsula) offered a way of demarcating Japan's peripheral sea boundary with the Asian mainland (Koida, 2018).

There are also myths connected with islands in Korean culture, which reveal cultural interaction between Jeju Island (Korea), the Zhoushan archipelago (China), and the Ryūkyū Islands (present-day Japan) (Heo \& Lee, 2018). The Jeju culture of Tamna-guk (state) was separate to the Korean peninsula and formed its own creation myth based on island ontology (Heo \& Lee, 2018, p. 173). The foundation myth notes the Byeongnang-guk Kingdom, which was at first thought to be Japan, although "this connection was made by adapting the narrative in such a way as to support historical and rational explanations" (Heo \& Lee, 2018, p. 173). The significance of such mythological accounts is that they show the importance of islands in their respective cultures, especially as spiritual locations.

As a sea dotted with many islands, the Japanese notion of archipelago or tatōkai 多島海 (many, islands, sea) helps explain a nation that literally comprises thousands of islands, and, for many islanders, the existence of such an array of islands would be a recognized geocultural aspect of everyday life. Importantly, this notion embraces sea and land. Hayward (2012) expands on this, while drawing on linguist Danny Long, and comments that "while the term [tatōkai] does not imply any profound holistic interrelation of terrestrial and marine environments it does provide a common reference for both aquatic and terrestrial spaces" (Hayward, 2012, pp. 4-5). With the Kojiki, while many islands are mentioned throughout the work, and grounded in the opening chapters, what is important is that they are envisioned within an archipelagic setting and this grouping of islands should be understood from such a perspective. That is, the "goal is to (re)inscribe the theoretical, metaphorical, real and empirical power and potential of the archipelago: of seas studded with islands; island chains; relations that may embrace equivalence, mutual relation and difference in signification" (Stratford et al, 2011, p. 113).

Following this introduction, the article divides into three main parts. The first examines the mythical island of Onokoro (Onogoro) 淤能碁呂島 as the first island in the making of Japan, and considers several locations that use its name in the present day. In the Kojiki, the idea of 'many islands' is introduced, and this is considered in the second part of the discussion in terms of actual or former islands in Japan in their order of appearance in the chronicle. The last section of the article discusses these islands as border islands, focusing on their creation through myth and mapping territory and important locations within the growing nation state. 


\section{Onokoro 淤能碁呂島}

The Kojiki was commissioned by Emperor Tenmu (reigned 672-686). As a chronicle with a Shintō origin myth (kuniumi) at its core, the work frames the basis of the imperial Japanese state (i.e., ancient Japan and centred on the Yamato Province, around present-day Nara). The Kojiki opens within the age of the gods (kamiyo/jindai) and notes that: "After seven generations of gods are created [...], the last generation, a male and a female god called Izanagi and Izanami, create the islands of Japan" (Shirane, 2007, pp. 21-22). The deities request that Izanagi (He Who Invites) and Izanami (She Who Invites) descend to the land below in order to create order. Walking out onto the floating bridge, which is thought to be a rainbow (Philippi, 1969, p. 49), the two deities use a spear to produce the island Onokoro (Figure 1). After descending to this island, they create 14 islands (a group of eight followed by a group of six) and 35 deities. The story offers a dualism with the two gods, a phallic spear through which islands are created, and a founding principle that Japanese islands are objects of divine origin. That is, "the idea of a sacred and divine genesis of the Japanese islands did not disappear, and has survived until today [...] not as the description of the creation of the Earth, but as the account of the birth of the sacred Japanese archipelago and of the sacred Japanese nation" (Barbaro, 2009, p. 28).

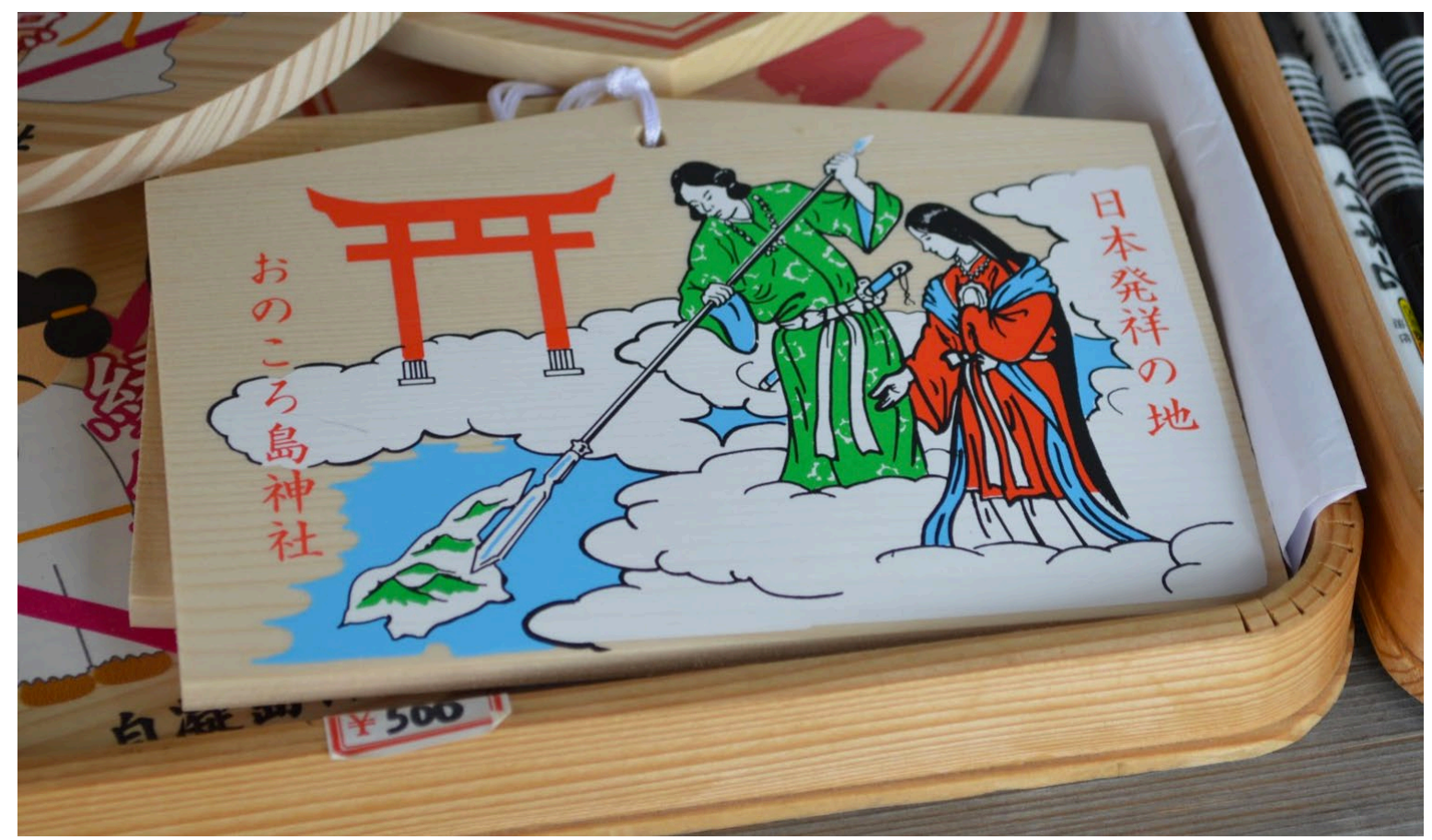

Figure 1. Ema (wooden Shintō plaque) at Onokoro-jima-jinja. Depicting the creation of Onokoro. Photo by Henry Johnson, (C) 2018.

The first island mentioned in the Kojiki is Onokoro ('self-curdling island'; Philippi, 1969 , p. 49). As the first island mentioned, and one that is distinctly foregrounded with its own section early in the Kojiki, Onokoro is identified in this discussion as a Japanese phenomenon that should be afforded due consideration when examining mythological islanding across geographic, social, and cultural terrains. While most of the other islands in the Kojiki, and some of the other mythological histories (noted above), have names that are 
either the same or very similar to ones used in the present day, Onokoro is essentially a mythical island that was a starting point in the creation of Japan. However, as discussed later, there are several islands and locations that today claim to be, or to represent, Onokoro.

Onokoro was created when the gods Izanagi and Izanami put a spear into the sea and, when pulling the spear from the water, the drips that fell formed the island (Philippi, 1969, p. 49). The sea sets the scene in the Kojiki in that land, or islands, were formed from it. In connection with land, Onokoro has geocultural significance in the mythological account of Japan as it was the first island to be created and occupied by the two deities, from which further gods and islands were born. The account places importance on the physicality of the island in terms of the physical beginnings of Japan, and especially with the religious connections that connect the gods with the emperor in that, at least until the end of the Second World War in 1945, the emperor was seen as a living descendant of the gods who created Japan.

The connection between Onokoro and a real island has been pointed out in Japanese studies of the text, and especially in the Kojiki-den, which is a discussion of the Kojiki by Motoori Norinaga (1730-1801), although no single theory has convincingly identified the island except that the location is thought to be “in the vicinity of Awaji [Island 淡路島]" (Philippi, 1969, p. 540). However, in connection with the islands and/or locations that today contend to be Onokoro, Herbert (2011, p. 255) notes five theories that locate the island as, on, or near to Awaji (Figure 2):

- Onokoro is Awaji Island 淡路島. However, Awaji is mentioned separately in the Kojiki.

- Onokoro is a hillock near Enami 榎列 in the south of Awaji. There is a shrine called Onokoro-jima-jinja おのころ島神社 at this location.

- Onokoro may be the islands Eshima 絵島 or Nushima 沼島. The former is just off the north of Awaji, and the latter off the south coast and with a shrine called Onokoro-jinja 自凝神社.

- Onokoro may be a mountain range in the west of Awaji at present-day Anaga-mura (Village) 阿那賀村.

- Onokoro is the island of Ōzo 大園島 to the southwest of Awaji. 


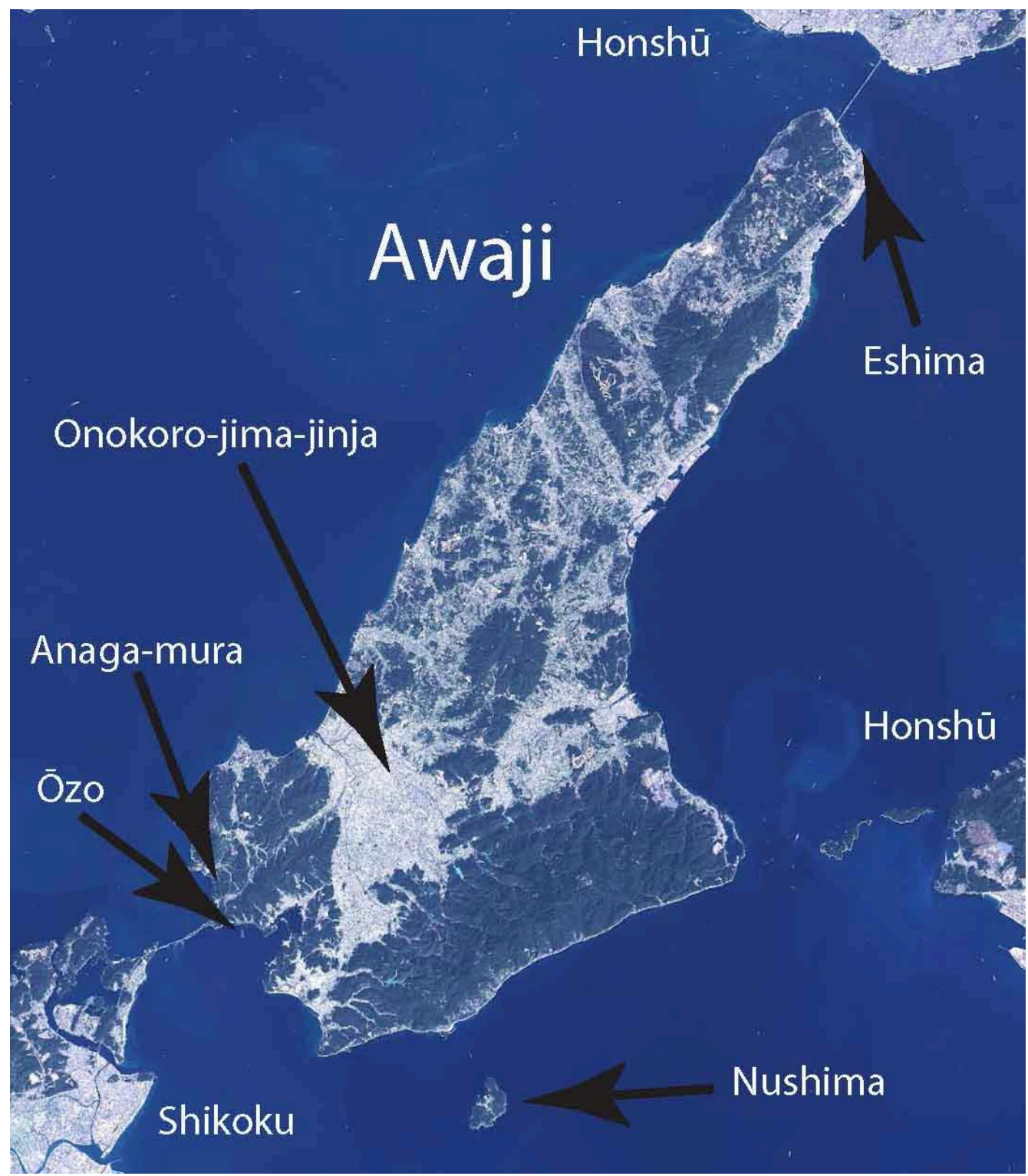

Figure 2. Possible locations of Onokoro Island. Edited map of original, courtesy of Geospatial Information Authority of Japan, https://maps.gsi.go.jp.

Rather than investigating every claim that a current location has for being Onokoro, two examples are now explored in order to help show the significance of the mythological island in the making of Japan. Each of these locations claiming to be Onokoro as noted above are located on or near to Awaji Island, which is Japan's eleventh-largest island at $592 \mathrm{~km}^{2}$. As a whole, Awaji is often recognized as being Onokoro. The name of the island means literally the 'road to Awa [province]', which is the name of a former region of which the island was a part. Awaji 淡路 and Awa province 阿波 share the pronunciation of 'awa' in their names, but not their kanji (Japanese ideographs). This indicates its close proximity to Honshū 本州 $(3.5 \mathrm{~km})$ and Shikoku 四国 $(1.3 \mathrm{~km}$ to Oge Island 大毛島 and $200 \mathrm{~m}$ farther to Shikok; today, Awaji is joined to Honshū and Shikoku by bridges). While now administered as part of Hyōgo Prefecture (most of which is on Honshū), and divided into three cities, Awaji has a number of near-shore and offshore islands, several of which claim to be Onokoro. 


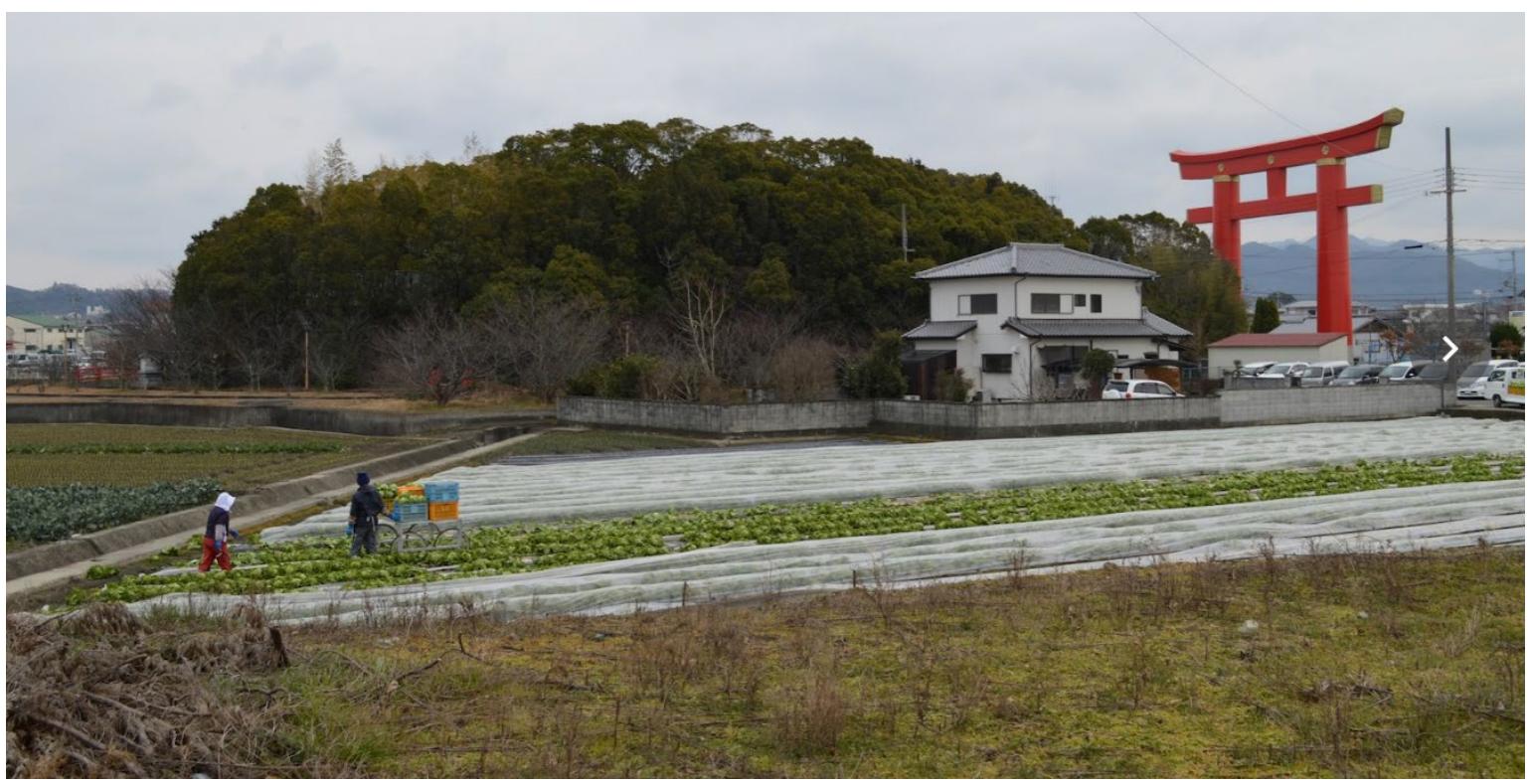

Figure 3. Shintō gate at Onokoro-jima-jinja. Photo by Henry Johnson, CC 2018.

On Awaji itself, one location that claims an Onokoro connection is Onokoro-jimajinja (Onokoro Island Shrine). The Shintō shrine is dedicated to the two deities, Izanagi and Izanami. A 21.7 meter-high vermilion-colored torii (Shintō gate) was built in 1982 and provides an eye-catching symbol representing the importance given to the location. In connection with the physical environment of the shrine, the location is a knoll that stands out in comparison with the open land that surrounds it (Figure 3). Another location that claims an Onokoro connection is Eshima, which is a bridged island just metres from its Awaji mainland (Figure 4). Its name means 'Picture Island', and it comprises a tiny sandstone island that was once joined to the mainland. While acknowledging different possible locations for Onokoro, a public notice at Eshima notes: "Usually, Awaji island has been believed as 'Onokoro Island' but some people believe that 'Eshima island' is actually 'Onokoro island'."

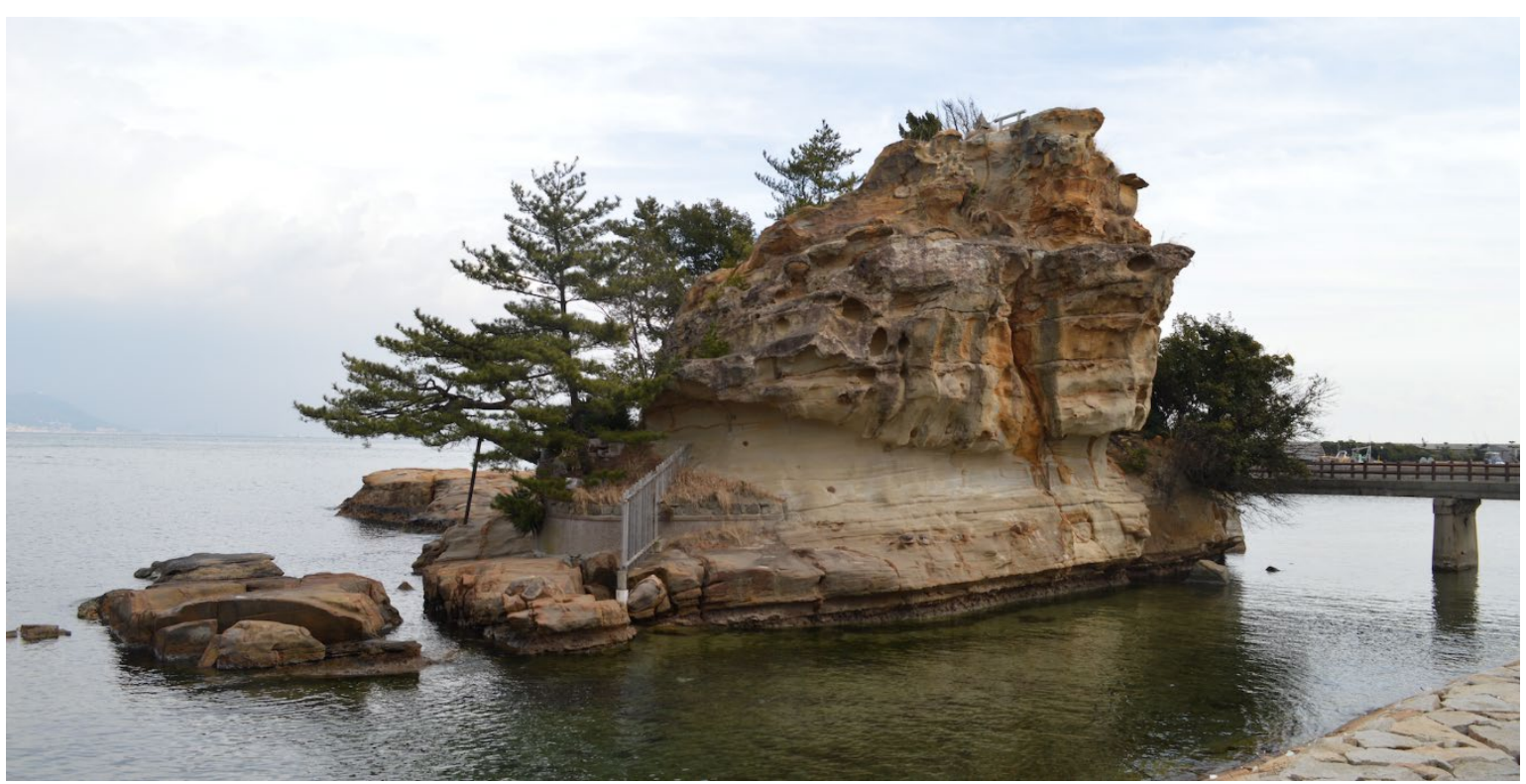

Figure 4. Eshima. Photo by Henry Johnson, (C) 2018. 
Whether or not Onokoro is a mythical or actual island is contested in the present day, with different locations having distinct connections to the name Onokoro and its creation story as outlined in the Kojiki. What is clear is that Onokoro has multiple locations, each of which constructs cultural meaning for those who connect to the site. Each of these settings are islands, ranging in size but by far the majority pointing to geographical features that are characterized by prominent features that are either conspicuous on their own as small islands or in terms of standing out on larger islands.

\section{'Many islands'}

The creation of Onokoro offered a conceptual starting point for Japan to be formed. As well as a number of islands mentioned at various parts throughout the Kojiki, the very notion of Japan as an archipelagic state is offered with the term yashima 八島 (eight/many islands). The notion of Japan originating with a composition of these islands provides an archipelagic framework for defining a geocultural realm. A broader definition of the term may refer to 'many islands', thus extending Japan to a nation comprising many islands and the ones referred to being representative islands that help serve the purpose of establishing the nation's history as well as its physical and maritime boundaries. That is, in Japanese, the term ' $y a$ ' (eight), as in yashima, "was a sacred number and could also mean a "great many" (Shirane, 2007, p. 853).

The idea of the term yashima signifying many islands as opposed to eight is reinforced by the number of islands that actually make up the state. While today the Japanese nation is defined by having 6852 islands (Kuwahara, 2012, p. 38), in the early $8^{\text {th }}$ Century, the number was much less. At that time, Japan had not colonized the island of Hokkaidō 北海道 in the north (Mason, 2012), nor many of the small islands in the Nansei archipelago to the southwest (Smits, 2019). Nevertheless, even if a substantial number of islands were removed from the current list of nearly 7000 islands, there would certainly be well more than the notional figure of eight as mentioned in the Kojiki. One might suppose that the eight islands were symbolic of the breadth of Japan in terms of being an island nation, but also representing significant locations within the archipelagic state (Batten, 2003, pp. 92-98).

Before looking more closely at the eight islands themselves, it will suffice to note that their depiction within the Kojiki served several purposes, including an imperial reinforcing of Japan's mythological island origins, helping depict Japan as comprising a number of small and large islands, and relating those island territories at the boundaries of the state (some of the islands are border islands between Japan and the Asian mainland, and also occupy seascapes where land is a small point within the important space of the ocean, as discussed later).

Chapter 6 of the Kojiki offers a succinct depiction of the birth of the Japanese islands, and in the English translation this occupies just two pages (Philippi, 1969, pp. 53-54). In order of birth, the group of eight main islands are (Figure 5): 
Table 1. Yashima.

\begin{tabular}{|c|c|c|c|}
\hline Names in the Kojiki & $\begin{array}{l}\text { Island (modern- } \\
\text { day name) }\end{array}$ & Notes & $\mathbf{k m}^{2 \star \star}$ \\
\hline $\begin{array}{l}\text { Apadi-nö-po-nö-sa-wakë-nö- } \\
\text { sima }\end{array}$ & Awaji 淡路 & Has several offshore islands & 592.51 \\
\hline Iÿ̈ & Shikoku 四国 & Has many offshore islands & $18,297.41$ \\
\hline Oki; Amë-nö-osi-körö-wake & Oki 隠岐 & Archipelago & 342.62 \\
\hline Tsukusi & Kyūshū 九州 & Has many offshore islands & $36,782.50$ \\
\hline Iki; Amë-pitötu-basira & Iki 壱岐 & Has several offshore islands & 134.63 \\
\hline $\begin{array}{l}\text { Tu-sima; Amë-nö-sade-yöri- } \\
\text { pime }\end{array}$ & Tsushima 対馬 & Has several offshore islands & 695.74 \\
\hline Sado & Sado 佐渡 & & 854.79 \\
\hline $\begin{array}{l}\text { Opo-yamatö-töyö-aki-tu- } \\
\text { sima; Ama-tu-mi-sora-töyö- } \\
\text { aki-tu-ne-wakë }\end{array}$ & Honshū 本州 & Has many offshore islands & $227,941.39$ \\
\hline
\end{tabular}

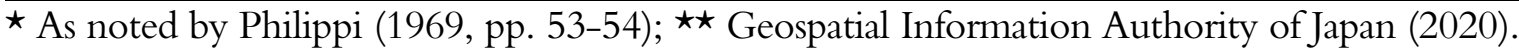

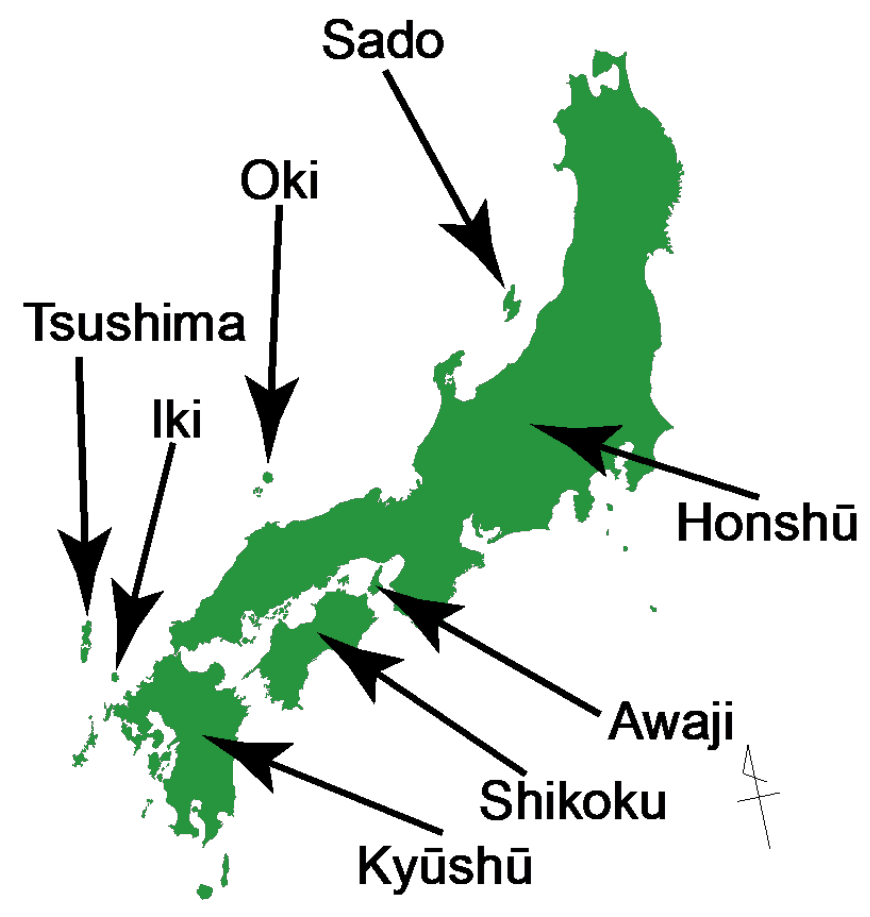

Figure 5. 'Many islands' (Yashima). Edited map of original courtesy of Technocco (テクノ コ白地図イラスト), https://technocco.jp.

The largest of these islands is Honshū, which is many times larger than Japan's smaller islands. Its islandness is evident not only with its contemporary bridge and tunnel links to Japan's three other large islands, but also through historical factors such as coastal settlement and maritime cultural geography (Bestor \& Bestor, 2014). Further, as with the other islands noted, Honshū 
has numerous small islands scattered around its coast and beyond. One of the smallest of the islands noted in this part of the Kojiki is Oki. Oki is actually a small archipelago comprising the larger island of Dōgo 島後島 $\left(241.55 \mathrm{~km}^{2}\right)$, a cluster of three small islands (Nishi no Shima 西ノ島, Naka no Shima 中ノ島, and Chiburi 知夫里島), and several much smaller islands. Such was the importance of Oki that the small group of islands was formed into Oki Province in the $7^{\text {th }}$ Century. The smallest island, Iki, has several very small offshore islands. In this setting, the idea of yashima would refer to many islands, but indexes islands as homelands, mapping Japan and consolidating the idea of nationhood in an imperial religiopolitical context.

At the end of the yashima chapter, six further islands are named (Figure 6):

Table 2. Six further islands.

\begin{tabular}{|c|c|c|c|}
\hline $\begin{array}{l}\text { Names in the } \\
K_{\text {Kojiki }} \star\end{array}$ & $\begin{array}{l}\text { Island (modern- } \\
\text { day name) }\end{array}$ & Notes & $\mathbf{k m}^{2 \star \star}$ \\
\hline $\begin{array}{l}\text { Kibï-nö-kozima; } \\
\text { Take-pi-kata-wake }\end{array}$ & Kojima 児島 & $\begin{array}{l}\text { Former island in the Seto } \\
\text { Inland Sea now part of } \\
\text { Honshū }\end{array}$ & Unknown \\
\hline $\begin{array}{l}\text { Adukï-sima; Opo- } \\
\text { no-de-pime }\end{array}$ & $\begin{array}{l}\text { Shōdo-shima } \\
\text { 小豆島 }\end{array}$ & An island near Awaji & 153.26 \\
\hline $\begin{array}{l}\text { Opo-sima; Opo- } \\
\text { tamaru-wakë }\end{array}$ & $\begin{array}{l}\text { Suō Ōshima } \\
\text { 周防大島 }\end{array}$ & $\begin{array}{l}\text { Also called Yashiro Island } \\
\text { 屋代島 }\end{array}$ & 128.48 \\
\hline $\begin{array}{l}\text { Pime-zima; Amë- } \\
\text { pitötu-ne }\end{array}$ & Hime-shima 姫島 & & 6.98 \\
\hline $\begin{array}{l}\text { Tika-nö-sima; } \\
\text { Amë-nö-osi-wo }\end{array}$ & Gotō五島 & $\begin{array}{l}\text { Five main islands, plus other } \\
\text { smaller islands }\end{array}$ & Fukue: 326.36 \\
\hline $\begin{array}{l}\text { Puta-go-nö-sima; } \\
\text { Amë-puta-ya }\end{array}$ & Danjo 男女群島 & $\begin{array}{l}\text { Two main islands, plus } \\
\text { other smaller islands }\end{array}$ & $\begin{array}{l}\text { Oshima 男島: } 2.50 \\
\text { Meshima 女島: } 1.22\end{array}$ \\
\hline
\end{tabular}

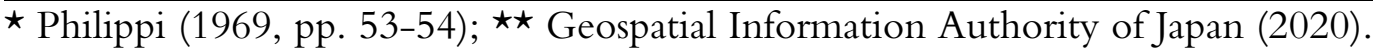




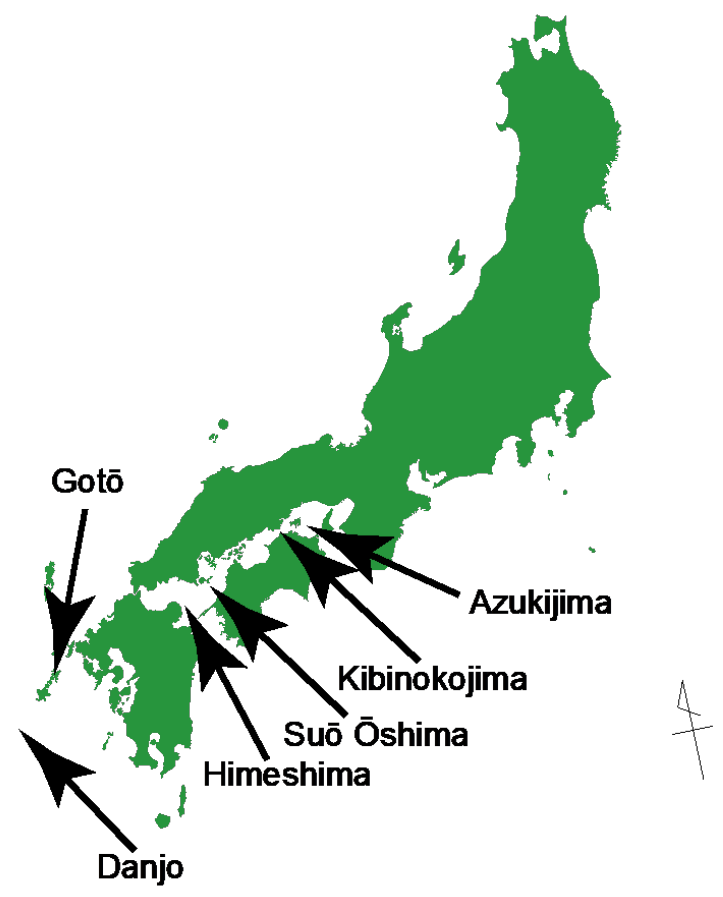

Figure 6. Six other islands. Edited map of original courtesy of Technocco (テクノコ白地図 イラスト), https://technocco.jp.

These six islands offer further significant interconnections between islands that were considered important enough in the early- $8^{\text {th }}$ Century to be mentioned in the Kojiki, possibly as trading hubs, the locations of important local rulers, or having geocultural ritual importance (Philippi, 1969, pp. 12-13). Some, however, are no longer separate islands. For example, Kojima, which is nowadays a city, was originally an island, but in 1618 it was joined to mainland Honshū (Otani, 2020). As noted by the city in connection with its place in the Kojiki: "Why would Kojima be given as the first-created of the following [six] islands? It is likely that, being in the inland sea, Kojima received attention for being an important transportation hub between Shikoku and western Japan" (Otani, 2020). Overall, the yashima and six further islands show locations that vary significantly in size, ranging from very small islands to Honshū, and that reveal a blending of island definitions: cultural locations as spaces of belonging.

\section{Border islands}

The Kojiki's eight principal islands may relate to the claimed boundaries of the authority of the Yamato Court, which had in 710 established a new capital in inland Heijō-kyō (presentday Nara), and was still consolidating authority over some regional provinces (kuni). While Yamato's control had expanded northward through Honshū, and south to Kyūshū and offshore islands, in the early- $8^{\text {th }}$ Century Japan covered a much smaller land and sea territory than it does today. At this time, Yamato had control of, or authority in, 60 provinces that each recognized the authority of the emperor (Naoki, 1993, p. 232). In the Japanese archipelago of the time, the provinces were located from the south of Kyūshū to the area of about present-day Sendai City towards the north of Honshū. The far northern provinces of Mutsu and Dewa on Honshū were the frontiers (hen' $y \bar{o})$ of the state and were still pushing out the indigenous Emishi until 802 (Yiengpruksawan, 1998, p. 18). It was only in the $19^{\text {th }}$ 
Century that Japan formally incorporated Hokkaido into the newly structured nation-state, as well as the former Ryūkyū Kingdom in the southwestern islands, which became Okinawa prefecture (Batten, 2003). In ancient Japan, the geographic perspective of the country was such that it was actually a small island that marked its 'northern' border, which related to the narrative mapping of territory in the Kojiki. That is, "the idea that Sado forms the northern boundary, rather than some point in northern Honshū, suggests that the curve of Honshū was not yet understood" (Unno, 1994, p. 366).

The naming of eight physical islands in the Kojiki offers a discursive mapping of some Japanese land masses that reflected important Japanese geographic parameters at the time. This charting of place and space, as a "topology of boundaries" (Kanazawa, 2018, p. 1), relates not only to small and large island landmasses, but also the seascape that lies between them. This phenomenon is especially significant in connection with fisheries where islands have importance in terms of marking locations, offering shelter and supplies, and connecting cultures through trade routes. In this context, important relationships regarding Japanese cartography and mythological accounts of Japan have been asserted in connection with both the Kojiki and the Nihon Shoki:

Both works are indifferent to the size of the islands. This is especially so in the Kojiki, in which the names of small islands in the Inland Sea, the Sea of Japan, the Straits of Tsushima, and the East China Sea are recorded in order of their creation. This suggests that such islands were important to navigators, who were likely to have visited the Asian mainland even before the Japanese missions to the Chinese court in A.D. 57 and 107. (Unno, 1994, pp. 353-354)

For a regime with a recent history of mainland Asian conflict, and with those neighbours having their own claims to islands off their shores, Japan's jurisdictional claims were envisioned through the Kojiki and later works and consolidated through religious and political subjugation (Batten, 2003).

Japan's interconnection between land and sea is especially evident not only with the somewhat pervious sea boundaries between Japan and different locations on the Asian mainland, but also in terms of the significance of the sea around small islands. For example, "the Yamato court conducted religious ceremonies on Okinoshima [Oki] to ensure safe passage on the sea routes to the continent" (Batten, 2003, p. 29). In terms of Oki's location as an offshore island and facing the Asian mainland, as noted by Batten (2003, p. 29), "the island itself may have served as a sort of primitive 'boundary marker' for the early Japanese state." After all, Oki is one of the smallest islands in the yashima group, and strategically situated between Honshū and the Korean Peninsula, near to two other such islands: Iki and Tsushima. Further, regarding Tsushima and the division between Korea and Japan, "the border consisted of a vague belt of ocean; it was a maritime frontier, as opposed to a boundary" (Batten, 2003, p. 30). However, in terms of the broader setting, the islands were the land boundary markers on the Japanese side in that the "the western border cannot be identified with precision, in part because it was located at sea, not on land" (Batten, 2003, p. 30). At the time of the Kojiki, Yamato was engaged very much in a process of nation building that was primarily concerned with gaining political support of the provinces, as well as pushing northward through Honshū 
where the northern provinces were the vaguely defined frontiers of the state over many centuries and with conflict between indigenous Emishi and Yamato colonizers.

Islands are important in marking national territory. This is especially applicable for mainlands/islands and near-shore/offshore islands. For Japan, in the present day, the nation's geographic land and sea borders are marked by and around recognized and claimed islands. Placed in a contemporary perspective, geopolitical contestation over islands in the Sea of Japan/East Sea, which has been evident in recent years with the Dokdo/Takeshima 竹島 and Diaoyu/Senkaku 尖閣諸島 disputes between the Republic of Korea and Japan, and China and Japan respectively (Baldacchino, 2017), illustrates the importance of islands and the sea around them as markers of territory. As Kuwahara (2012, p. 39) comments in connection with the Japanese archipelago, "one of the most noticeable roles of the outer islands is the securement of territory." While modern-day border islands are farther outlying than most of those noted in the Kojiki, this island/border connection relates also to ancient Japan in terms of "securing of national territory" (Kuwahara, 2012, p. 44).

Even though state boundaries became more distinct in the $8^{\text {th }}$ Century, there were clear areas of Japan's main island and island territory that still had fluid divisions, particularly in the north of Honshū and in the southwest:

During the Nara period, [...] the establishment of a strong, centralized state was associated with the emergence of an imperial ideology; the recognition of a clear distinction between incorporated 'inner lands' [kenai] and unincorporated 'outer lands' [kegai]; and an ongoing attempt to convert the latter into the former through a process of territorial expansion. (Batten, 2003, pp. 34-35)

The inner lands/islands were around and within the Inland Sea, between Honshū and Shikoku, and bordering Kyūshū to the west. The outer lands/islands were on the extremes of the nation as envisioned from the Yamato perspective (i.e., Sado, Oki, Iki, Tsushima), and on the front line with Japan's Asian mainland neighbours. This was a marking of Japan's geographic claim in the face of the Silla (57 BC-AD 935) and Balhae (698-926) states (on the Korean peninsula and to its north respectively), and with the Chinese Tang dynasty to the west.

The $7^{\text {th }}$ Century saw the first direct conflict between Yamato and the Chinese Tang dynasty, which was fought on the Korean peninsula and with the Battle of Baekgang (663) being a major Japanese military defeat. By establishing clearer borders with islands marking distinct points within the state, the Yamato Court was reflecting similar nation-building on the Asian mainland, especially with the quickly expanding states of Silla and Balhae and the Chinese Tang dynasty. Yamato was creating an Other outside of its claimed boundaries, but was also demarcating recognized internal locations (Kanazawa, 2018, p. 1). Further, ancient Japan had maintained close links with the Asian mainland, including Gaya (42-562) and Baekje (18 BC-660) on the Korean Peninsula, and in the $6^{\text {th }}$ and $7^{\text {th }}$ Centuries Yamato helped the latter against Silla, although Japan was defeated by the Silla-Tang offensive that eventually saw Silla dominate much of the Korean peninsula (Kim, 2012). The depiction of the birth of the Japanese archipelago in the Kojiki helped Japan consolidate its imperial nation-building through geographical reference points based on distinct island locations (Brownlee, 1987, p. 118), particularly with four of the eight islands being small yet relatively closer to the Asian 
mainland than were Japan's larger islands. It is here that the geo-mythological foundations of the Japanese landscape are defined by not only an archipelago of mostly small islands, and the three larger islands of Honshū, Kyūshū, and Shikoku, but also by the seascape between these islands and the Asian mainland. Japan's nation-building is therefore part of an assemblage of land, sea, and myth.

\section{Conclusion}

Japan's Inland Sea and the coastal waters of its main islands have multitudinous small islands that form both a physical pathway across land, and a seascape that extends territorial limits into sea routes used for trade and defence. This sphere of island corporeality links with spiritual power, as exercised through imperial sovereignty, and maps territorial borders, routes, and locations that are conspicuous through geographic borderlines or socio-cultural substance.

The Kojiki depicts a mythological and historical account of Japan in the early- $8^{\text {th }}$ Century. Embracing a religiopolitical ideology, the chronicle consolidates the interconnection between Japan's indigenous belief system and imperial rule as well as maps real and imagined islands as markers of terrestrial and cosmological ontology. As well as the dispersion of islands as coordinates of place and space, islands in the Kojiki are emblems of cultural significance by their very existence in this early source book of Japanese history, myth, and national origins. Japan's first island, Onokoro, is symbolic and at the core of demarcating cultural origins, which are manifested in several island locations, many of which are on, around, or near to Awaji in the Inland Sea. Further islands form part of the creation myth and are featured either as Japan's larger islands or as near-shore or offshore small islands.

This discussion has contributed to island studies from historical and cultural perspectives. It has shown that mythological islanding permeates geographic, social, and cultural terrains. In the Kojiki, islands are particularly relevant as physical markers of geocultural importance in Japan's origin myths, and are locations that help in comprehending what islands mean in this archipelagic setting. That is, the study of islands and myths reiterates the importance of deconstructing concepts of islands. After all, "a key point of contention within the field has revolved around the definition of the 'island' itself and the appropriate subject matter of island studies” (Luo \& Grydehøj, 2017, p. 27).

\section{References}

Antoni, K. (2011). Creating a sacred narrative: Kojiki studies and Shintō nationalism. Japanese Religions, 36(1-2), 3-30.

Baldacchino, G. (2008). Islands in between: Martín García and other geopolitical flashpoints. Island Studies Journal, 3(2), 211-224.

Baldacchino, G. (2017). Solution protocols to festering island disputes. Routledge. https://doi.org/10.4324/9781315574707

Barbaro, P. (2009). Explanations of the Earth's features and origin in pre-Meiji Japan. In M. Kölbl-Ebert (Ed.). Geology and religion: A history of harmony and hostility (pp. 25-36). The Geological Society. https://doi.org/10.1144/SP310.4

Batten, B.L. (2003). To the ends of Japan: Premodern frontiers, boundaries, and interactions. University of Hawai'i Press. https://doi.org/10.1515/9780824865207 
Bestor, V.L. \& Bestor, T.C. (2014). Japan and the sea. Education about Asia, 19(2), 50-56. Brownlee, J.S. (1987). Ideological control in ancient Japan. Historical Reflections, 14(1), 113-133. Brownlee, J.S. (1991). Political thought in Japanese historical writing: From Kojiki (712) to Tokushi Yoron (1712). Wilfrid Laurier University Press.

Durrell, L. (1953). Reflections on a Marine Venus: A companion to the landscape of Rhodes. Faber and Faber.

Duthie, T. (2015). Yoshino and the politics of cultural topography in early Japan. Monumental Nipponica, 70(2), 189-235. https://doi.org/10.1353/mni.2015.0023

Geospatial Information Authority of Japan. (2020). Shima menseki [Island area]. https://www.gsi.go.jp/KOKUJYOHO/MENCHO202001-index.html

Gillis, J.R. (2007). Island sojourns. Geographical Review, 97(2), 274-287. https://doi.org/10.1111/j.1931-0846.2007.tb00403.x

Hayward, P. (2012). Aquapelagos and aquapelagic assemblages: Towards an integrated study of island societies and marine environments. Shima, 6(1), 1-11.

Heldt, G. (2014). Introduction. In Ō, Y. The Kojiki: An account of ancient matters. G. Heldt (Trans.). Columbia University Press.

Heo, N.C. \& Lee, H.J. (2018). Sea deity beliefs of the Kuroshio oceanic cultural sphere: maritime traditions and cultural interaction among Jeju Island, Zhoushan Archipelago, and the Ryukyu Islands. Island Studies Journal, 13(1), 171-184. https://doi.org/10.24043/isj.55

Herbert, J. (2011). Shintô: At the fountain-head of Japan. Routledge. https://doi.org/10.4324/9780203842164

Iwashita, A. (2016). Nyūmon kokkyōgaku: Ryōdo, shuken, ideorogī. Chūkō Shinsho.

Kanazawa, H. (2018). The topology of boundaries. I. Wang (Trans.). Studies in Japanese Literature and Culture, 1, 1-14.

Kim, J. (2012). A history of Korea: From 'Land of the Morning Calm' to states in conflict. Indiana University Press.

Koida, T. (2018). Chikura Sea: A marine border between Japan and Tang China. K. Reeves (Trans.). Studies in Japanese Literature and Culture, 1, 33-37. https://doi.org/10.7221/sjlc01.001.0

Kōnoshi, T. (2000). Constructing Imperial mythology: Kojiki and Nihon Shoki. In: H. Shirane \& T. Suzuki (Eds). Inventing the classics: Modernity, national identity, and Japanese literature (pp. 51-67). Stanford University Press.

Kuwahara, S. (2012). The development of small islands in Japan: An historical perspective. Journal of Marine and Island Cultures, 1, 38-45. https://doi.org/10.1016/j.imic.2012.04.004

Lewis, M.W. \& Wigen, K.E. (1997). The myth of continents: A critique of metageography. University of California Press. https://doi.org/10.1525/9780520918597

Luo, B. \& Grydehøj, A. (2017). Sacred islands and island symbolism in Ancient and Imperial China: An exercise in decolonial island studies. Island Studies Journal, 12(2), 25-44. https://doi.org/10.24043/isj.19

MacKinnon, S.R. (2020). Seasteads and aquapelagos: Introducing nissology to speculativefiction studies. Fafnir: Nordic Journal of Science Fiction and Fantasy Research, 7(1), 27-41. 
Mason, M. (2012). Dominant narratives of colonial Hokkaido and Imperial Japan: Envisioning the periphery and the modern nation-state. Palgrave Macmillan. https://doi.org/10.1057/9781137330888

McCall, G. (1994). Nissology: A proposal for consideration. Journal of the Pacific Society, 17, $1-14$.

Miner, E., Odagiri, H., \& Morrell, R.E. (1985). The Princeton companion to classical Japanese literature. Princeton University Press. https://doi.org/10.1515/9780691218380

Naoki, K. (1993). The Nara state. F.G. Bock (Trans.). In D.M. Brown (Ed.). The Cambridge history of Japan. Volume 1. Ancient Japan (pp. 221-267). Cambridge University Press. https://doi.org/10.1017/CHOL9780521223522.007

Nelson, J.K. (2000). Enduring identities: The guise of Shinto in contemporary Japan. University of Hawai'i Press. https://doi.org/10.1515/9780824862381

Ōno, Yasumaro [Ō no Yasumaro]. (1803). Teisei kokun kojiki. 3 vols. Kawanami Gihei et al.

Otani, T. (2020). Long ago, Kojima was an island!. Kojima Chamber of Commerce. www.kojima-cci.or.jp/kojiki/kojiki-English.pdf

Palmer, E. (1994). Beyond geography: The geography of the beyond in ancient Japan. GeoJournal, 33, 479-485.

Philippi, D.L. (1969). Kojiki. Translated with an introduction and notes. University of Tokyo Press and Princeton University Press.

Plutschow, H.E. 1995. Japan's name culture: The significance of names in a religious, political context. Japan Library.

Sakamoto, T. (1991). The six national histories of Japan. J.S. Brownlee (Trans.). University of British Columbia Press.

Shirane, H. (Ed.) (2007). Traditional Japanese literature: An anthology, beginnings to 1600. Columbia University Press.

Smits, G. (019). Maritime Ryukyu, 1050-1650. University of Hawai'i Press.

Stratford, E., Baldacchino, G., McMahon, E., Farbotko, C., \& Harwood, A. (2011). Envisioning the archipelago. Island Studies Journal, 6(2), 113-130.

Suwa, J. (2007). The space of shima. Shima, 1(1), 6-14.

Suwa, J. (2017). Becoming island: The aquapelagic assemblage of Benten-sai festivals on Sakurajima, in Sai Village, northern Japan. Shima, 11(2), 5-19. https://doi.org/10.21463/shima.11.2.04

Tuan, Y.F. (1974). Topophilia: A study of environmental perception, attitudes, and values. Prentice-Hall.

Unno, K. (1994). Cartography in Japan. In J.B. Harley \& D. Woodward (Eds.). The history of cartography: Volume two, book two: Cartography in the traditional East and Southeast Asian societies (pp. 346-477). University of Chicago Press.

Yiengpruksawan, M.H. (1998). Hiraizumi: Buddhist art and regional politics in twelfth-century Japan. Harvard University Asia Center. https://doi.org/10.1163/9781684173136 